\title{
Media Pembelajaran Puzzle Angka dan Corong Angka (PANCORAN) Bagi Anak Berkebutuhan Khusus (ABK)
}

\section{Lisna Sari ${ }^{1}$, Ryan Angga Pratama², Besse Intan Permatasari ${ }^{3}$}

\author{
1,2,3 Pendidikan Matematika, Universitas Balikpapan, Indonesia \\ Corresponding Author: ryan.angga@uniba-bpn.ac.id², lisnafairus1993@gmail.com', \\ besse.intan@uniba-bpn.ac.id ${ }^{3}$
}

DOI: http://dx.doi.org/10.15294/kreano.v11i1.23618

Received: March 2 2020; Accepted: April 14 2020; Published: June 12020

\begin{abstract}
Abstrak
Penelitian ini bertujuan untuk menghasilkan media pembelajaran Puzzle Angka dan Corong Angka (PANCORAN) yang layak digunakan dalam materi Bilangan untuk siswa kelas 5 Tunagrahita di Sekolah Luar Biasa (SLB) Tunas Bangsa Balikpapan. Penelitian ini merupakan kategori penelitian dan pengembangan (R\&D), dengan metode pengembangan model Borg \& Gall yang dimodifikasi dengan tahapan yang dilakukan sebagai berikut: (1) penelitian dan pengumpulan informasi awal, (2) perencanaan, (3) pengembangan format produk awal, (4) uji coba awal, (5) revisi produk, (6) uji coba lapangan, (7) revisi produk. Hasil validasi menunjukkan bahwa media pembelajaran Puzzle Angka dan Corong Angka (PANCORAN) yang dikembangkan termasuk kategori Sangat Valid (rata-rata skor 4,75$)$, Sangat Praktis (skor 4,7), dan Efektif (ketuntasan belajar siswa mencapai 80\%).
\end{abstract}

Kata kunci: puzzle angka; corong angka; tunagrahita

\begin{abstract}
This study aims to produce learning media for Number Puzzle and Number Funnel (PANCORAN) that are suitable for use in Numbers material for Grade 5 Tunagrahita students at Tunas Bangsa Special Schools (SLB) Balikpapan. This research is a research and development $(R \& D)$ category, with the method of developing the modified Borg \& Gall model with the following stages: (1) initial research and preliminary data collection, (2) planning, (3) developing the initial product format, (4) initial trials, (5) product revisions, (6) field trials, (7) product revisions. The results of the validation show that the learning media for Number Puzzle and Number Funnel (PANCORAN) developed is in the category of Very Valid (average score 4,75), Very Practical (score $4,7)$, and Effective (the percentage of completeness of student learning outcomes reaches $80 \%$ ).
\end{abstract}

Keywords: number puzzle; number funnel; tunagrahita

\section{PENDAHULUAN}

Pendidikan merupakan suatu proses timbal-balik dari tiap pribadi manusia dalam penyesuaian diri dengan alam, teman, orang tua, dan alam semesta, serta merupakan perkembangan yang teroganisasi dan kelengkapan dari semua potensi manusia dari moral, intelektual, jasmani, dan untuk kepribadian individu dalam kegunaan kemasyarakatannya yang diarahkan demi menghimpun semua aktivitas tersebut untuk tujuan hidupnya (Ahmadi, 2016). Undang-Undang Dasar 1945 pasal 31 ayat 1 menjamin setiap warga negara untuk memperoleh kesempatan yang sama, salah satunya memperoleh pendidikan. Hal ini menunjukkan bahwa anak yang memiliki 
kebutuhan khusus berhak pula memperoleh kesempatan yang sama dengan anak lainnya (anak normal) dalam pendidikan. Selain itu juga Undang-Undang Nomor 20 Tahun 2003 tentang Sistem Pendidikan Nasional Pasal 32 ayat 1 menjelaskan pendidikan khusus (pendidikan luar biasa) merupakan pendidikan bagi siswa yang memiliki tingkat kesulitan dalam mengikuti proses pembelajaran karena kelainan fisik, emosional, mental, dan sosial dan/ atau memiliki potensi kecerdasan dan bakat istimewa (Fauzy, 2015).

Anak Berkebutuhan Khusus (ABK) adalah anak yang berbeda dengan anak pada umumnya, tanpa selalu menunjukan pada kekurangan mental, emosi, atau fisik (Shanty, 2012). Peraturan Pemerintah Republik Indonesia Nomor 72 Tahun 1991 menjelaskan bahwa Anak Berkebutuhan Khusus (ABK) yang mengalami reterdasi mental disebut tunagrahita. Tunagrahita adalah anak yang mempunyai tingkat kecerdasan yang jauh di bawah anak-anak dengan tingkat kecerdasan yang normal sehingga, membutuhkan pelayanan pendidikan khusus (Murtie, 2016). Berdasarkan skala wescheler, anak tunagrahita dibedakan menjadi tunagrahita ringan bila IO antara 55-69, tunagrahita sedang bila $\mathrm{IO}$ antara 40-54, tunagrahita berat bila IO diantara 25-39, dan tunagrahita sangat berat bila IO 24 (Sudana, 2015).

Tunagrahita ringan merupakan suatu kondisi anak yang mengalami keterbelakangan perkembangan mental intelektual di bawah rata-rata, sehingga mengalami kesulitan dalam tugas-tugas akademik, komunikasi, dan sosial (Susanti, Yunus, \& Iswari, 2013). Tunagrahita sedang merupakan kondisi anak yang memiliki kemampuan intelektual berada di bawah kemampuan anak tunagrahita ringan, mengalami keterlambatan dalam bidang komprehensi dan penggunaan bahasa, pencapaian dalam mengurus diri dan kecakapan motorik juga terlambat, kemajuan di sekolah juga terbatas namun sebagian dari mereka dapat mempelajari kecakapan dasar yang dibutuhkan untuk membaca, menulis, dan menghitung (Suparti, 2010). Pendidikan luar biasa secara sadar memberikan pelayanan pendidikan dengan sebaik-baiknya, salah satu pelayanan akademik yang diberikan Sekolah
Luar Biasa (SLB) kepada anak berkebutuhan khusus adalah pelajaran matematika. Menurut Pratama (2018), matematika merupakan ilmu yang bersifat umum, mendasari perkembangan teknologi modern, berperan penting dalam berbagai disiplin ilmu, dan mengembangkan daya pikir manusia (Pratama, 2018). Mata pelajaran matematika sebagai salah satu mata pelajaran wajib di sekolah, maka perlu adanya penguasaan konsep matematika yang kuat sejak dini, serta dapat menumbuhkan kemampuan siswa dalam berpikir logis, analitis, sistematis, kritis, kreatif, dan bekerja sama.

Siswa SLB sangat berbeda dengan siswa pada sekolah formal sehingga membutuhkan perlakuan khusus dalam semua pelajaran termasuk matematika. Berdasarkan pendapat tersebut, layanan pendidikan yang diberikan untuk Anak Berkebutuhan Khusus (ABK) tidak sama dengan anak normal lainnya karena harus dirancang secara khusus dari tujuan, strategi belajar berupa penerapan media dan metode, serta evaluasi pembelajaran yang bertujuan tidak hanya berorientasi untuk mengembangkan keterampilan semata juga mengembangkan kecerdasan intelektual dan kecerdasan emosional yang patut mendapat perhatian dari guru kelas atau guru yang mengajar di kelas (Maulida \& Zulfitria, 2018). Dalam proses belajar mengajar matematika, selain melibatkan pendidik atau guru dan siswa secara langsung, diperlukan juga pendukung yang lain seperti alat pelajaran yang memadai, penggunaan model atau metode pembelajaran yang tepat, penggunaan media pembelajaran yang menarik, serta situasi dan kondisi lingkungan yang menunjang.

Media pembelajaran adalah segala bentuk sesuatu yang dapat menyampaikan dan menyalurkan pesan dari berbagai sumber secara terencana sehingga tercipta lingkungan belajar yang kondusif dimana penerimanya dapat melakukan proses belajar secara efisien dan efektif (Munadi, 2013). Media merupakan salah satu bagian dari komunikasi, yaitu sebagai pembawa pesan dari pemberi pesan menuju penerima pesan, sehingga proses pembelajaran merupakan proses komunikasi (Daryanto, 2013). Selain itu pengertian lainnya, media pembelajaran adalah alat-alat 
grafis, fotografis, atau elektronis untuk menangkap, memproses, dan menyusun kembali informasi visual atau verbal (Arsyad, 2015). Pemakaian media pembelajaran dalam proses belajar akan sangat baik karena dapat menumbuhkan rasa ingin tahu yang tinggi dan minat yang baru, juga dapat membangkitkan motivasi dan rangsangan kegiatan belajar, serta dapat membawa pengaruh psikologis yang baik terhadap siswa (Suwastarini, Dantes, \& Candiasa, 2015). Semua anak usia sekolah yang mengalami kelainan berhak mendapatkan layanan pendidikan yang sama dengan siswa pada umumnya (Rahayu, 2013).

Berdasarkan hasil observasi di SLB Tunas Bangsa Balikpapan, pada hari Rabu tanggal 13 Februari 2019 siswa kelas 5 SD Tunagrahita di sekolah tersebut masih banyak yang belum mengenal bilangan dan masih banyak siswa yang belum bisa berhitung seperti operasi penjumlahan dan pengurangan. Guru sudah menggunakan media pembelajaran dalam menjelaskan materi Bilangan yaitu berupa media gambar yang dipasang di papan tulis, namun siswa masih belum paham karena media tersebut hanya dilihat tetapi belum dirasakan langsung atau siswa tidak ikut berperan langsung dalam belajar menggunakan media pembelajaran. Oleh sebab itu, kreativitas seorang guru sangat diperlukan dalam memodifikasi dan menciptakan suasana belajar yang beragam dan menarik untuk Anak Berkebutuhan Khusus (ABK) Tunagrahita, salah satunya dengan mengembangkan media pembelajaran dengan harapan media tersebut dapat menarik perhatian siswa lebih bersemangat dalam belajar dan berperan langsung dalam belajar menggunakan media pembelajaran sehingga siswa akan lebih mengerti dan mengingat materi yang dijelaskan.

Salah satu solusi media yang diharapkan dapat mendukung pembelajaran Anak Berkebutuhan Khusus (ABK) di SLB Tunas Bangsa Balikpapan adalah dengan mengembangkan media pembelajaran Puzzle Angka dan Corong Angka (PANCORAN) dimana media Puzzle Angka akan membantu mengenalkan bilangan 1 sampai dengan 10 dan dengan media Corong Angka siswa diajak untuk menghitung operasi penjumlahan dan pengurangan dengan sangat menyenangkan sehingga diharapkan dapat meningkatkan motivasi belajar, semangat belajar, hasil belajar, meningkatkan daya ingat, aktif dalam proses pembelajaran, mampu mengembangkan kemampuan yang dimilikinya, dan mampu memahami materi dan konsep dalam matematika.

Selain itu, media pembelajaran Puzzle Angka dan Corong Angka (PANCORAN) juga akan dilengkapi dengan beberapa atribut yang erat kaitannya dengan kearifan lokal Balikpapan sekaligus mengenalkan kepada siswa bahwa kota Balikpapan juga memiliki kearifan lokal yang tidak dimiliki daerah lain. Kearifan lokal menurut Gosal (2012) merupakan suatu pemikiran yang tersusun secara terencana yang hidup dalam masyarakat, tumbuh dan berkembang secara terus-menerus dalam kesadaran masyarakat, berfungsi dalam mengatur kehidupan masyarakat dari yang sifatnya berkaitan dengan kehidupan yang sakral maupun duniawi. Selanjutnya, Wagiran (2012) juga berpendapat bahwa kearifan lokal dalam bahasa asing sering diartikan sebagai kebijakan dari suatu wilayah setempat, pengetahuan dari suatu wilayah setempat, atau kecerdasan dari suatu wilayah setempat.

Kearifan lokal di kota Balikpapan sangatlah beragam mulai dari buah, hewan, bunga atau tanaman, pakaian, batik dan masih banyak lainnya. Dalam penelitian ini peneliti memilih Beruang Madu dan Kain Batik sebagai kearifan lokal Balikpapan yang akan dikenalkan kepada siswa. Batik memiliki ciri khas berdasarkan daerah masing masing. Kain batik Balikpapan mempunyai banyak motif yang beragam salah satunya motif Ampiek Balikpapan yang merupakan kolaborasi antara ukiran Dayak dengan Mangrove. Berikut gambar dari kearifan lokal Balikpapan.

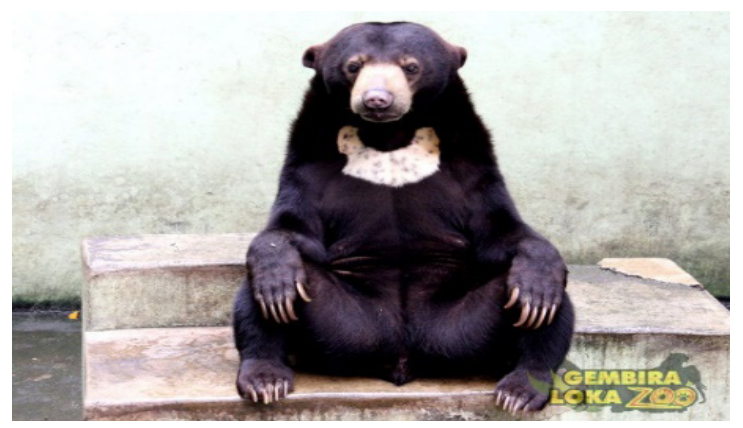

Gambar 1. Beruang Madu

Sumber: http://gembiralokazoo.com/collection/ beruang-madu.html 


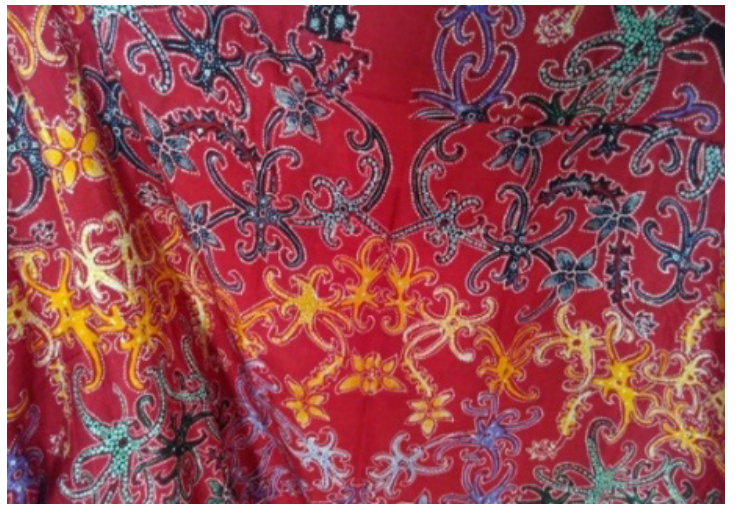

Gambar 2. Motif Batik Ampiek

Sumber: https://infobatik.id/batik-ampiek/

Beberapa penelitian relevan juga menunjukan bahwa terdapat pengaruh yang signifikan dari penggunaan media pembelajaran untuk membantu proses belajar mengajar anak tunagrahita yaitu penelitian dari Susanti, Yunus, \& Iswari (2013) yang menjelaskan bahwa media Pita Garis Bilangan efektif dalam meningkatkan kemampuan penjumlahan bagi anak tunagrahita ringan. Selain itu, penelitian dari Putri (2014) yang mengungkapkan bahwa media Kartu yang Bergambar Domino dapat meningkatkan kemampuan penjumlahan yang hasilnya kurang dari 20 bagi anak tunagrahita ringan. Selanjutnya, penelitian dari Fauzy (2015) yang menjelaskan bahwa dengan menggunakan media Manik-Manik dapat meningkatkan hasil belajar anak tunagrahita.

Berdasarkan permasalahan serta potensi-potensi yang ada, sehingga peneliti merasa perlu melakukan suatu pengembangan media pembelajaran bagi Anak Berkebutuhan Khusus (ABK) Tunagrahita yang diberi nama Puzzle Angka dan Corong Angka (PANCORAN) sekaligus mengenalkan kearifan lo- kal Balikpapan.

\section{METODE}

Penelitian ini termasuk kategori penelitian dan pengembangan (R\&D). Adapun metode pengembangannya menggunakan model Borg \& Gall yang dimodifikasi Sugiyono (2016) yang terdiri dari 10 langkah namun dimodifikasi lagi oleh peneliti menjadi 7 langkah dikarenakan keterbatasan dan disesuaikan kebutuhan peneliti (Gambar 3).

Berdasarkan siklus pada Gambar 3, rangkuman beberapa tahapan utama dalam penelitian ini adalah:

\section{Pendahuluan dan Perencanaan}

Pada tahapan ini, dilakukan kegiatan yang meliputi studi literatur, yakni mencari dan menemukan bahan kajian pustaka, penelitian yang relevan berkaitan dengan media pembelajaran bagi Anak Berkebutuhan Khusus (ABK), konsep dan landasan teoritis untuk memperkuat produk yang akan dikembangkan, identifikasi permasalahan pembelajaran yang dialami guru, wawancara dengan Kepala Sekolah dan Guru Matematika SDLB Tunas Bangsa Balikpapan, mengkaji materi Mengenal Angka, dan merangkumnya ke dalam catatan sebagai bahan dalam melakukan proses pengembangan produk pada tahap selanjutnya.

\section{Pengembangan Produk Awal}

Pada tahapan ini, dilakukan perencanaan dan perumusan tujuan khusus yang ingin dicapai dari media pembelajaran yang akan dikembangkan, penentuan urutan bahan dan materi, serta uji ahli atau uji coba pada skala

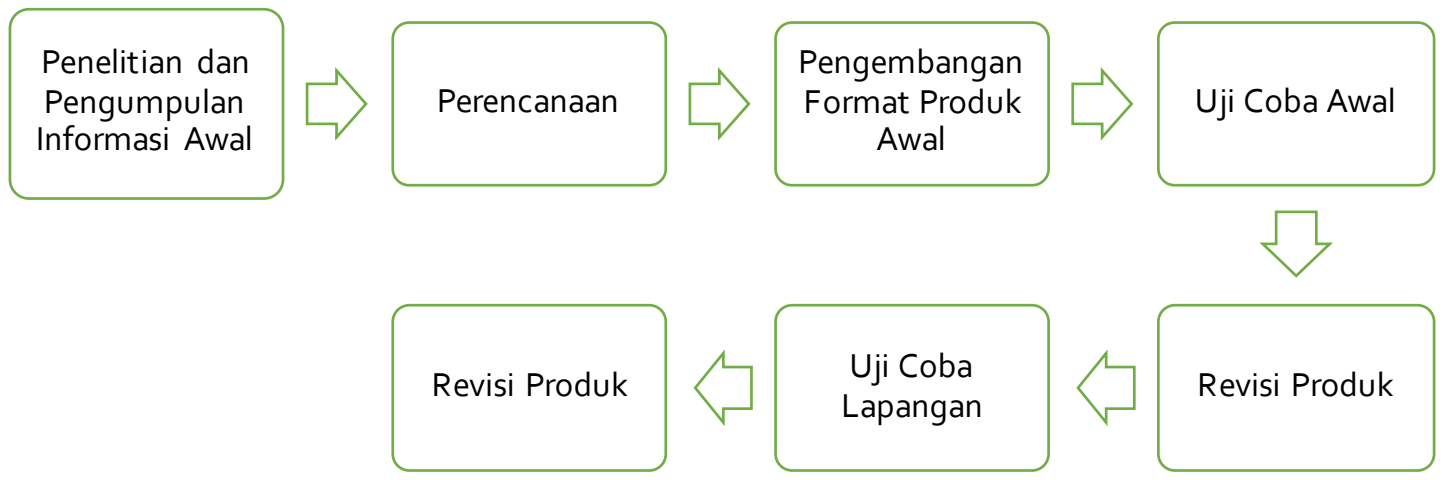

Gambar 3. Langkah-langkah R\&D yang dimodifikasi (Setyosari, 2013; Sugiyono, 2016) 
kecil. Peneliti juga mulai melakukan pengembangan format produk awal yang mencakup penyiapan alat dan bahan seperti gunting, lem, kertas karton, kain flannel, gambar Beruang Madu, kain Batik Ampiek, serta konsep materi pembelajaran.

\section{Pelaksanaan (Validasi, Revisi, dan Ujicoba)}

Validasi produk dilakukan oleh dua ahli media pembelajaran, dua ahli materi, serta satu praktisi/guru. Adapun desain validasinya adalah validasi isi (content validity) dimana kelompok ahli mengisi instrumen berupa angket dan memberi kritik atau saran terhadap produk yang dikembangkan agar selanjutnya dapat direvisi. Selanjutnya, uji coba dilakukan kepada pengguna untuk mengetahui kualitas produk yang dikembangkan. Subjek coba media pembelajaran Puzzle Angka dan Corong Angka (PANCORAN) adalah seluruh siswa tunagrahita di SDLB Tunas Bangsa Balikpapan, dan pelaksanaan uji cobanya menggunakan desain One-Shot Case Study. Uji Coba Awal dilaksanakan dengan melibatkan 2 siswa tunagrahita di SDLB Tunas Bangsa Balikpapan, sedangkan Uji Coba Lapangan dilaksanakan dengan melibatkan 5 siswa tunagrahita di SDLB Tunas Bangsa Balikpapan.

Adapun teknik pengumpulan data dilakukan dengan beberapa teknik, yaitu: (a) Wawancara; dilakukan terhadap Kepala Sekolah dan Guru Matematika SDLB Tunas Bangsa Balikpapan; (b) Studi Dokumentasi; untuk mengkaji beberapa literatur terkait, menggali data berupa catatan, foto, dan data lainnya sesuai fokus penelitian, serta langkah konkret serangkaian pelaksanaan pengembangan media pembelajaran Puzzle Angka dan Corong Angka (PANCORAN); (c) Angket; disusun sesuai peran dan posisi subjek data yang terdiri dari angket untuk ahli media, ahli materi, serta praktisi/guru.

Berdasarkan tahapan penelitian dan pengembangan yang digunakan, jenis data yang diperoleh bersifat kuantitatif dan kualitatif. Data kuantitatif berupa skor yang diperoleh dari angket penilaian produk pengembangan untuk ahli media, ahli materi, serta praktisi/guru yang disusun dengan Skala Likert. Selanjutnya, data kuantitatif yang dipe- roleh tersebut dihitung dengan teknik analisis data persentase yang dirumuskan sebagai berikut:

\section{Teknik Analisis Data Kevalidan \\ Menggunakan rumus:}

$$
\bar{V}=\frac{\sum_{i=1}^{n} X_{i}}{n}
$$

Keterangan: Skor total validitas; : Skor validator ke-l; dan : Banyaknya item pernyataan

Selanjutnya, rumus menghitung ratarata dari semua validator sebagai berikut:

$$
\bar{X}=\frac{\sum_{i=1}^{n} \overline{V_{i}}}{n}
$$

Keterangan : Rata-rata total semua validator; : Rata-rata validasi validator ke-l; : Banyaknya validator (Sudijono, 2010)

Selanjutnya, hasil yang diperoleh akan dikonversikan dengan kriteria penilaian kevalidan pada tabel di bawah ini:

Tabel 1. Kriteria Penilaian Kevalidan Produk

\begin{tabular}{cc}
\hline Kriteria Ketuntasan & Keterangan \\
\hline $1 \leq X<1,8$ & Tidak Valid \\
$1,8 \leq X<2,6$ & Kurang Valid \\
$2,6 \leq X<3,4$ & Cukup Valid \\
$3,4 \leq X<4,2$ & Valid \\
$4,2 \leq X \leq 5$ & Sangat Valid \\
\hline Widoyoko (Yuliana, 2017)
\end{tabular}

Teknik Analisis Data Kepraktisan Menggunakan rumus:

$$
\bar{P}=\frac{\sum_{i=1}^{n} \overline{P_{i}}}{n}
$$

Keterangan: : Skor kepraktisan; : Skor kepraktisan validator ke-I; : Banyaknya item pernyataan

$$
\text { (Sudijono, 2010) }
$$

Selanjutnya hasil yang diperoleh dikonversikan dengan kriteria penilaian kepraktisan pada tabel di bawah ini: 
Tabel 2. Kriteria Penilaian Kepraktisan Produk

\begin{tabular}{cc}
\hline Kriteria Ketuntasan & Keterangan \\
\hline $1 \leq \mathrm{P}^{-}<1,8$ & Tidak Praktis \\
$1,8 \leq \mathrm{P}^{-}<2,6$ & Kurang Praktis \\
$2,6 \leq \mathrm{P}^{-}<3,4$ & Cukup Praktis \\
$3,4 \leq \mathrm{P}^{-}<4,2$ & Praktis \\
$4,2 \leq \mathrm{P}^{-} \leq 5$ & Sangat Praktis \\
\hline Widoyoko (Yuliana, 2017, P. 64)
\end{tabular}

\section{Teknik Analisis Data Keefektifan} Menggunakan Rumus:

$$
P=\frac{P_{a}}{P_{b}} \times 100 \%
$$

Keterangan: : Persentase ketuntasan siswa; : Jumlah siswa yang tuntas; : Jumlah siswa keseluruhan.

(Sudijono, 2010)

Media pembelajaran dikatakan efektif apabila hasil belajar siswa tunagrahita mendapatkan nilai minimal sesuai KKM yaitu 65 serta persentase ketuntasan siswa berada di interval 60\% sampai dengan $80 \%$. Data hasil belajar ini dikonversikan dengan tabel kriteria penilaian keefektifan di bawah ini:

Tabel 3. Kriteria Penilaian Keefektifan Produk

\begin{tabular}{cc}
\hline $\begin{array}{c}\text { Persentase } \\
\text { Ketuntasan }\end{array}$ & Keterangan \\
\hline $\mathrm{P}>80 \%$ & Sangat Efektif \\
$60 \%<\mathrm{P} \leq 80 \%$ & Efektif \\
$40 \%<\mathrm{P} \leq 60 \%$ & Cukup Efektif \\
$20 \%<\mathrm{P} \leq 40 \%$ & Kurang Efektif \\
$\mathrm{P} \leq 20 \%$ & Tidak Efektif \\
\hline Widoyoko (Yuliana, 2017, P. 64)
\end{tabular}

\section{HASIL DAN PEMBAHASAN}

Tahap pengembangan Puzzle Angka dan Corong Angka (PANCORAN) menggunakan model Borg dan Gall yang diadaptasi sesuai dengan kebutuhan peneliti. Berikut hasil yang diperoleh:

\section{Penelitian dan pengumpulan infor- masi awal}

Peneliti melakukan observasi ke seko- lah yang telah dipilih yaitu SLB Tunas Bangsa Balikpapan, observasi ini bertujuan untuk mendapatkan seputar informasi sekolah, informasi siswa, serta mencari tahu materi yang sulit dipahami oleh siswa dalam pembelajaran matematika. Selain itu peneliti melakukan pemilihan kelas yang akan diteliti, kelas yang terpilih adalah kelas 5 SD tunagrahita, dimana terdapat 7 orang siswa tunagrahita dan dalam pelajaran matematika materi yang kurang dipahami siswa adalah materi Bilangan.

\section{Perencanaan}

Pada tahap perencanaan, peneliti merencanakan pengembangan media yang dapat digunakan sesuai dengan Materi Bilangan, mudah digunakan dan sangat menyenangkan untuk siswa Tunagrahita. Media pembelajaran yang dikembangkan peneliti diharapkan dapat mengenalkan angka 1 sampai dengan 10 dan memuat operasi pengurangan dan penjumlahan.

\section{Pengembangan format produk awal}

Pada tahap ini peneliti mengembangkan media Puzzle Angka dan Corong Angka yang diberi nama "PANCORAN". Langkah awal dari pembuatan media ini yaitu menentukan bahan dan menyiapkan alat yang dibutuhkan dari setiap media. Berikut alat dan bahan yang digunakan untuk membuat media pembelajaran:

Puzzle Angka. Alat yang dibutuhkan diantaranya pisau cutter, gunting, penggaris, pensil, dan spidol, sedangkan bahan yang digunakan adalah kardus.

Corong Angka. Alat yang dibutuhkan diantaranya meteran, gergaji, palu, pensil, spidol, pisau cutter, kuas, amplas kayu, steples tembak, mesin bor, dan mesin ketam. Sedangkan bahan yang dipakai diantaranya kayu jati belanda, kain batik ampiek, paku, lem FOX, isi staples, clear (pengkilap kayu), permen, botol plastik, dan cat minyak.

\section{Uji coba awal}

Sebelum melakukan uji coba, produk terlebih dahulu divalidasi oleh ahli. Validasi dilakukan oleh ahli media, ahli materi dan praktisi/guru. Ahli media menilai media pem- 
belajaran yang dikembangkan sesuai dengan pernyataan angket, kemudian memberi komentar dan saran yang mendukung penyempurnaan media. Sedangkan ahli materi mengoreksi soal tes dan menilai materi dengan angket yang diberikan, serta praktisi/guru memberikan tanggapan pada angket terkait pemanfaatan media dalam pembelajaran dikelas. Berikut disajikan penilaian dari masingmasing ahli tersebut:

\section{Hasil penilaian ahli media}

Konsep yang ada pada media pembelajaran sesuai dengan keterbatasan siswa tunagrahita, secara umum tidak terlalu banyak revisi untuk media pembelajaran yang dikembangkan. Adapun hasil validasi oleh ahli media secara berturut-turut dengan skor 4 dan 3,7 atau dengan rata-rata 3,9 (Valid).

\section{Hasil penilaian ahli materi}

Melihat soal-soal tes dengan kesesuaian materi yang akan diajarkan, secara umum sudah baik dan tidak banyak revisi. Adapun hasil validasi oleh ahli materi secara berturut-turut dengan skor 3,9 dan 3,9 atau dengan rata-rata 3,9 (Valid).

\section{Hasil penilaian praktisi/guru}

Penilaian praktisi/guru berkaitan dengan kepraktisan dari media pembelajaran yang dikembangkan dengan memberikan tanggapan terkait pemanfaatan media dalam keterlaksanaannya pada pembelajaran dikelas. Adapun hasil validasi oleh praktisi dengan skor 3,8 (Praktis).

Setelah semua validasi telah dilakukan, peneliti melakukan uji coba kecil terhadap 2 siswa. Uji coba ini dilakukan untuk melihat keefektifan dari media pembelajaran yang dikembangkan dengan memberikan soal tes secara lisan kepada siswa tunagrahita. Pertama-tama, peneliti mengenalkan media Puzzle Angka kepada anak, dimana puzzle tersebut akan dipisah dan mereka harus menyusun sesuai dengan pasangannya. Kemudian peneliti meminta siswa untuk mengurutkan puzzle tersebut dari angka 1 sampai dengan 10. Setelah siswa mahir menyusun dan mengurutkan puzzle angka, langkah selanjutnya peneliti menjelaskan cara kerja Corong Angka dengan menggunakan contoh-contoh soal yang sesuai dengan materi bilangan. Jika seluruh siswa sudah mengerti, selanjutnya peneliti masuk ke soal-soal berikutnya dengan meminta siswa mengambil beberapa permen dan menghitungnya sesuai dengan soal lisan yang diberikan peneliti.

Hasil uji coba ini selanjutnya dianalisis oleh peneliti untuk memperbaiki media pembelajaran yang dikembangkan. Berikut skor pencapaian hasil belajar siswa dalam menyelesaikan soal tes:

Tabel 4. Hasil Belajar Siswa Pada Uji Coba Lapangan

\begin{tabular}{ccc}
\hline No. & Nama Siswa & Nilai \\
\hline 1. & S-1 & 55 \\
2. & S-2 & 82 \\
\hline & Jumlah Nilai & 137 \\
\hline & Rata-Rata & 68,5 \\
\hline
\end{tabular}

Berdasarkan Tabel 4, terdapat satu siswa yang tidak tuntas. Hal ini dikarenakan siswa S-1 masih belum mengerti perintah atau pertanyaan yang diberikan peneliti, siswa yang tidak tuntas cenderung pemalu sehingga tidak terlalu memperhatikan saat peneliti menerangkan. Namun dilihat dari aktivitas siswa saat proses belajar, mereka sangat senang dan antusias dalam belajar menggunakan media pembelajaran Puzzle Angka dan Corong Angka (PANCORAN). Saat pembelajaran siswa duduk rapi di tempat duduknya dengan menyelesaikan soal-soal yang diberikan secara lisan.

\section{Revisi produk}

Produk yang telah diuji coba, kemudian direvisi sesuai dengan kritik dan saran dari para ahli media, ahli materi, dan praktisi/guru. Revisi atau perbaikan produk ini bertujuan untuk memaksimalkan penggunaan media pembelajaran yang dikembangkan. Beberapa revisi yang dilakukan dapat dilihat pada Tabel 5 .

Berdasarkan saran dari para ahli, dilakukanlah analisis dan proses revisi/perbaikan. Media pembelajaran semakin baik dalam segi penampilan maupun dalam segi bahan, selanjutnya, media pembelajaran PANCORAN dapat dilakukan uji coba kembali dalam uji coba lapangan. 
Tabel 5. Hasil Revisi Produk

Sebelum

Sesudah

Ahli Media:

a) Pada media corong angka, kurang banyak variasi warna.

a) Pada media corong angka, sudah diberi bebera-

b) Corong berbeda-beda ukuran.

c) Pada corong belum ada angka yang tertulis. pa warna kombinasi.

b) Corong sudah satu ukuran.

c) Pada corong sudah ada angka yang tertulis.
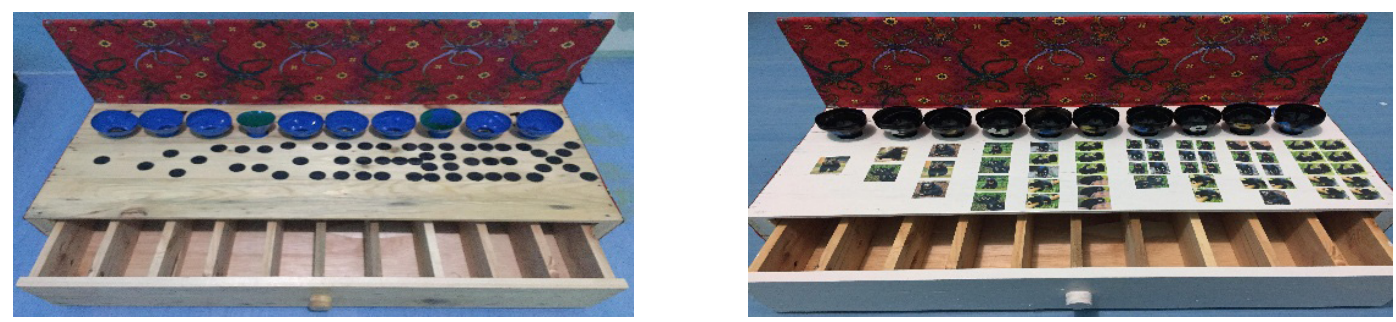

d) Pada media puzzle angka, bahan terbuat dari kardus.

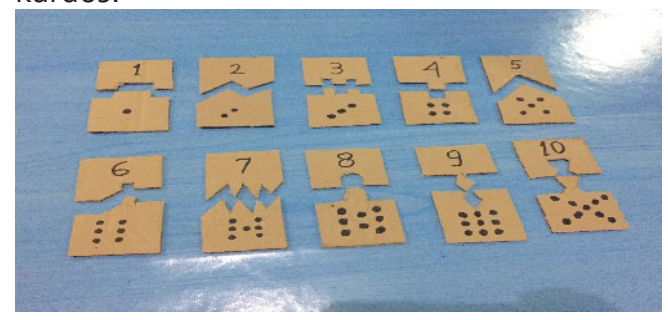

d) Pada media puzzle angka, bahan terbuat dari kayu.

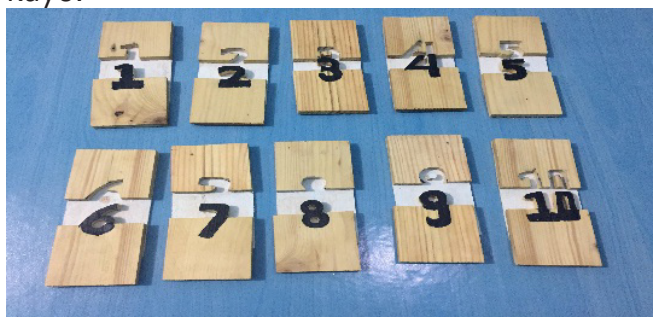

Ahli Materi:

Kalimat dalam soal tes masih kurang sederhana.

Kalimat dalam soal tes lebih disederhanakan.

Ani mempunyai 9 permen, ia memberikan 2 per-

Ani mempunyai g permen, ia memberikan 2 permenmennya kepada adik, kemudian Ani memberikan lagi 3 permen kepada kakaknya. Berapa sisa pernya kepada adik. Berapa sisa permen Ani sekarang? men Ani sekarang?

\section{Praktisi/Guru:}

Tidak ada gambar-gambar yang menarik pada corong angka.

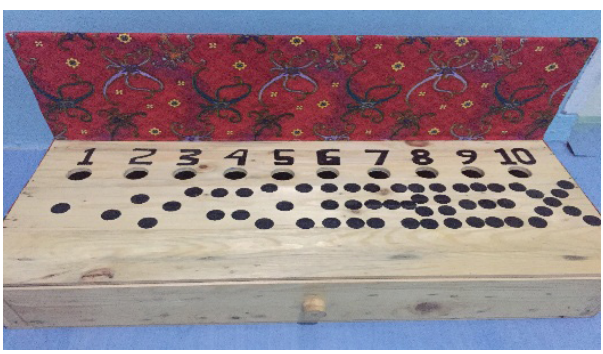

Sudah ada gambar-gambar Beruang Madu untuk berhitung pada corong angka.

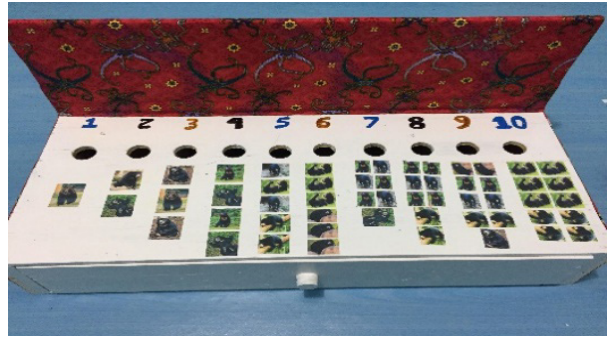

\section{Uji coba lapangan}

Sebelum melakukan uji coba lapangan terlebih dahulu dilakukan validasi oleh para ahli. Validasi ahli media, ahli materi dan praktisi/guru, yang divalidasi oleh validator yang sama seperti yang memvalidasi uji coba awal.
Dengan menggunakan media pembelajaran yang telah direvisi, berikut ulasan atau penilaian dari masing-masing para ahli:

\section{Hasil penilaian ahli media}

Dalam penilaian media yang telah dire- 
visi, media pembelajaran sudah sangat baik. Berikut hasil validasi oleh ahli media:

Tabel 6. Hasil Validasi Ahli Media Setelah Revisi

\begin{tabular}{|c|c|c|c|}
\hline \multirow{2}{*}{ Aspek } & \multicolumn{2}{|c|}{ Skor } & \multirow{2}{*}{$\begin{array}{l}\text { Rata- } \\
\text { Rata }\end{array}$} \\
\hline & Ahli 1 & Ahli 2 & \\
\hline $\begin{array}{l}\text { Kreativitas pembuatan } \\
\text { media }\end{array}$ & 5 & 5 & 5 \\
\hline Inovati media & 5 & 5 & 5 \\
\hline Keunggulan media & 4 & 5 & 4,5 \\
\hline Pengelolaan media & 5 & 5 & 5 \\
\hline Daya tahan media & 5 & 5 & 5 \\
\hline Efisiensi media & 4 & 4 & 4 \\
\hline Keefektifan media & 4 & 4 & 4 \\
\hline Kemenarikan media & 4 & 5 & 4,5 \\
\hline Pemilihan bahan & 5 & 5 & 5 \\
\hline Kesesuaian media & 5 & 5 & 5 \\
\hline Memuat materi ajar & 5 & 5 & 5 \\
\hline Media sederhana & 5 & 5 & 5 \\
\hline Tampilan media & 5 & 5 & 5 \\
\hline Sesuai kemampuan siswa & 5 & 5 & 5 \\
\hline Kemudahan media & 5 & 5 & 5 \\
\hline Jumlah skor & 71 & 73 & 72 \\
\hline Kriteria Ketuntasan & 4,7 & 4,9 & 4,8 \\
\hline Keterangan & $\begin{array}{c}\text { San- } \\
\text { gat } \\
\text { Valid }\end{array}$ & $\begin{array}{c}\text { San- } \\
\text { gat } \\
\text { Valid }\end{array}$ & $\begin{array}{c}\text { San- } \\
\text { gat } \\
\text { Valid }\end{array}$ \\
\hline
\end{tabular}

Berdasarkan Tabel 6, diketahui bahwa media pembelajaran PANCORAN dapat dikatakan Sangat Valid, serta kedua ahli hanya menyarankan agar nama media perlu dituliskan pada media pembelajaran yang dikembangkan.

\section{Hasil penilaian ahli materi}

Secara umum, materi dan soal-soal tes yang disajikan sudah sangat baik dan tidak melakukan revisi lagi. Berikut hasil validasil oleh ahli materi:

Tabel 7. Hasil Validasi Ahli Materi Setelah Revisi

\begin{tabular}{lccc}
\hline \multirow{2}{*}{ Aspek } & \multicolumn{2}{c}{ Skor } & Rata- \\
\cline { 2 - 3 } & Ahli 1 & Ahli 2 & Rata \\
\hline Ketepatan strategi & 5 & 4 & 4,5 \\
Kelengkapan materi & 5 & 5 & 5 \\
$\begin{array}{l}\text { Sesuai kemampuan } \\
\text { siswa }\end{array}$ & 5 & 5 & 5 \\
Kalimat jelas & 4 & 4 & 4 \\
Memotivasi siswa & 5 & 5 & 5 \\
\hline
\end{tabular}

\begin{tabular}{|c|c|c|c|}
\hline \multirow{2}{*}{ Aspek } & \multicolumn{2}{|c|}{ Skor } & \multirow{2}{*}{$\begin{array}{l}\text { Rata- } \\
\text { Rata }\end{array}$} \\
\hline & Ahli 1 & Ahli 2 & \\
\hline $\begin{array}{l}\text { Pemberian umpan } \\
\text { balik }\end{array}$ & 4 & 5 & 4,5 \\
\hline Kejelasan materi & 5 & 4 & 4,5 \\
\hline Pembahasan jelas & 5 & 4 & 4,5 \\
\hline Kedalaman materi & 4 & 4 & 4 \\
\hline Materi jadi mudah & 5 & 5 & 5 \\
\hline Mudah dipahami & 4 & 5 & 4,5 \\
\hline $\begin{array}{l}\text { Kesesuaian materi } \\
\text { dengan media }\end{array}$ & 5 & 5 & 5 \\
\hline Sesuai materi ajar & 5 & 5 & 5 \\
\hline $\begin{array}{l}\text { Kesesuaian soal dan } \\
\text { materi }\end{array}$ & 5 & 5 & 5 \\
\hline Menyelesaikan soal & 4 & 5 & 4,5 \\
\hline Jumlah skor & 70 & 70 & 70 \\
\hline Kriteria Ketuntasan & 4,7 & 4,7 & 4,7 \\
\hline Keterangan & $\begin{array}{l}\text { Sangat } \\
\text { Valid }\end{array}$ & $\begin{array}{l}\text { Sangat } \\
\text { Valid }\end{array}$ & $\begin{array}{l}\text { Sangat } \\
\text { Valid }\end{array}$ \\
\hline
\end{tabular}

Berdasarkan Tabel 7, diketahui bahwa materi dapat dikatakan Sangat Valid. Serta dari kedua ahli menyatakan bahwa materi tidak perlu dilakukan revisi kembali.

\section{Hasil penilaian praktisi/guru}

Revisi dilakukan sesuai dengan saran praktisi/ guru, berikut hasil penilaian praktisi/guru:

Tabel 8. Hasil Penilaian Praktis/ Guru Setelah Revisi

\begin{tabular}{ll}
\hline Pernyataan & Skor \\
\hline Terjadi umpan balik & 4 \\
Guru memberikan kesempatan siswa & 4 \\
Semua siswa mau mencoba & 5 \\
Guru membimbing siswa & 4 \\
Siswa aktif bertanya & 4 \\
Menambah semangat belajar & 5 \\
Meningkatkan hasil belajar siswa & 5 \\
Suasana menyenangkan & 5 \\
Tingginya keingintahuan siswa & 5 \\
Penyampaian materi mudah dipahami & 5 \\
Soal sesuai materi ajar & 5 \\
Kebermanfaatan media & 5 \\
Media menambah pemahaman materi & 5 \\
Media menambah pengetahuan siswa & 5 \\
Media mudah digunakan & 5 \\
Jumlah skor & 71 \\
Kriteria Ketuntasan & 4,7 \\
\hline Keterangan: Sangat Praktis
\end{tabular}

Keterangan: Sangat Praktis 
Berdasarkan hasil yang diperoleh pada Tabel 8, diketahui bahwa media pembelajaran PANCORAN dapat dikatakan Sangat Praktis. Hal itu ditinjau berdasarkan penilaian dari butir-butir angket dengan kriteria ketuntasan 4,7. Menurut praktisi tidak ada lagi yang perlu direvisi karena sudah sangat baik untuk dipelajari oleh siswa tunagrahita.

Setelah melakukan validasi barulah peneliti melakukan uji coba lapangan. Uji coba ini dilakukan untuk melihat keefektifan dari media pembelajaran yang dikembangkan dengan memberikan soal tes secara lisan kepada siswa tunagrahita. Hasil uji coba ini selanjutnya dianalisis oleh peneliti untuk mengetahui hasil belajar siswa menggunakan media pembelajaaran PANCORAN. Berikut skor pencapaian hasil belajar siswa dalam menyelesaikan soal tes:

Tabel 9. Hasil Belajar Siswa Pada Uji Coba Lapangan

\begin{tabular}{ccc}
\hline No. & Nama Siswa & Nilai \\
\hline 1. & $\mathrm{~S}-3$ & 79 \\
2. & $\mathrm{~S}-4$ & 73 \\
3. & $\mathrm{~S}-5$ & 100 \\
4. & $\mathrm{~S}-6$ & 64 \\
5. & $\mathrm{~S}-7$ & 91 \\
\hline \multicolumn{3}{c}{ Jumlah Nilai } \\
\hline \multicolumn{2}{c}{ Persentase Ketuntasan } \\
\hline
\end{tabular}

Berdasarkan data yang telah disajikan, dapat dikatakan siswa belum sepenuhnya mencapai skor ketuntasan. Terdapat satu siswa yang masih belum tuntas dikarenakan siswa kurang teliti dalam menjawab soal dan terburu-buru menghitung hasil. Namun dilihat dari aktivitas siswa saat proses belajar, mereka sangat senang dalam belajar menggunakan media pembelajaran Puzzle Angka dan Corong Angka (PANCORAN) terlihat dari siswa yang aktif saat diminta memasangkan puzzle, dan memasukan kelereng pada setiap corong. Siswa juga mendengarkan penjelasan dari peneliti saat menjelaskan materi menggunakan media pembelajaran. Saat pembelajaran, siswa lebih tenang dan duduk rapi di tempat duduknya dengan menyelesaikan soal-soal yang diberikan secara lisan. Dari 5 orang siswa, 4 siswa diantaranya mendapatkan nilai di atas KKM, sehingga persentase sis- wa yang tuntas adalah $80 \%$, dan masuk dalam kriteria Efektif.

\section{Revisi produk}

Revisi produk tahap akhir ini tidak banyak melainkan hanya penyempurnaannya saja karena sudah direvisi pada tahap awal, hanya perlu menambahkan nama produk pada media yang dikembangkan. Untuk tahapan media pembelajaran yang dikembangkan, sudah selesai sampai tahap ini dan tidak dilakukan tahapan selanjutnya dikarenakan keterbatasan peneliti.

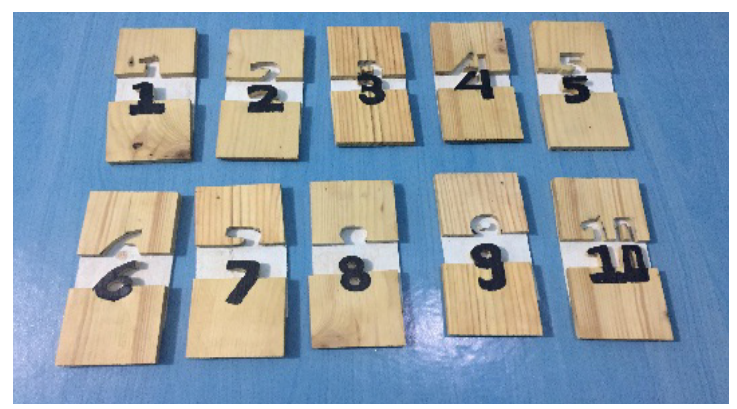

Gambar 4. Tampilan Puzzle Angka Tahap Akhir

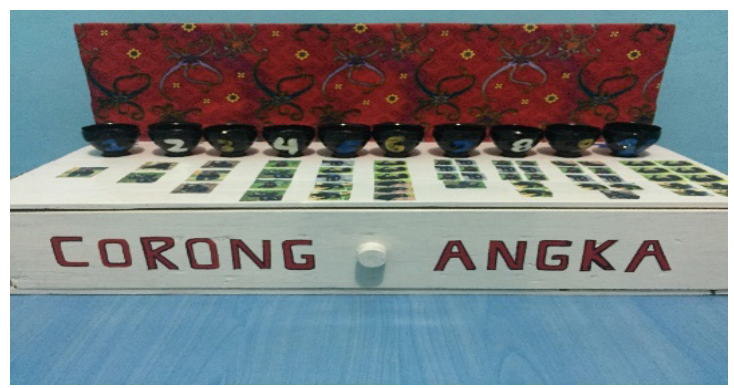

Gambar 5. Tampilan Corong Angka Tahap Akhir

Dalam pengembangan media pembelajaran memerhatikan aspek-aspek dalam menilai kualitas suatu produk yang dikembangkan yakni, kevalidan, kepraktisan, dan keefektifan. Pada pengujian media pembelajaran ini, divalidasi oleh ahli media, ahli materi, dan praktisi/guru. Berdasarkan hasil penilaian oleh para ahli dan uji coba yang dilakukan, berikut akan dijabarkan penjelasannya:

Pertama-tama, Media pembelajaran divalidasi oleh dua orang ahli media, yakni Dosen yang Mengampu Mata Kuliah Media Pembelajaran serta Guru Kelas 5 SDLB Tunas Bangsa Balikpapan. Dengan keahliannya, kedua validator tersebut menilai media 
pembelajaran yang dikembangkan dengan menggunakan instrumen angket penilaian. Instrumen angket untuk validasi ahli media dilakukan dua kali yaitu sebelum revisi dan setelah revisi media pembelajaran. Setelah dianalisis, hasil rata-rata validator tersebut adalah sebagai berikut:

Tabel 10. Hasil Rata-Rata Validasi Ahli Media

\begin{tabular}{ccc}
\hline & $\begin{array}{c}\text { Skor Rata- } \\
\text { Rata }\end{array}$ & Keterangan \\
\hline $\begin{array}{c}\text { Validasi ahli media } \\
\text { sebelum revisi } \\
\begin{array}{c}\text { Validasi ahli media } \\
\text { setelah revisi }\end{array}\end{array}$ & 3,9 & Valid \\
\hline
\end{tabular}

Pada hasil tabel dapat dilihat, bahwa pada kriteria ketuntasan media pembelajaran terjadi peningkatan sebesar 0,9 dengan keterangan yang awalnya media pembelajaran dikatakan Valid kini menjadi Sangat Valid. Hal ini membuktikan bahwa media pembelajaran sangat baik digunakan untuk anak Tunagrahita. Saran dan kritik dari ahli media adalah warna pada angka dan bulatan diberi warna yang menarik (setidaknya 3 warna kombinasi), corong diperbarui, media Puzzle Angka sebaiknya jangan menggunakan bahan dasar kardus akan tetapi berbahan dasar kayu karena jika menggunakan kardus akan mudah dirusak oleh siswa. Serta tampilan harus lebih bewarna agar menarik perhatian siswa. Dengan memerhatikan saran-saran dan kritikan dari kedua ahli, peneliti membuat media pembelajaran jauh nlebih baik dan menarik untuk dipelajari siswa Tunagrahita.

Selanjutnya, validasi oleh ahli materi yang dilakukan oleh dua orang ahli materi, yakni satu dosen Pendidikan Matematika Universitas Balikpapan dan satu Guru Matematika SDLB Tunas Bangsa Balikpapan. Dengan keahliannya, kedua validator tersebut menilai menggunakan instrumen angket penilaian. Instrumen angket untuk validasi ahli materi dilakukan dua kali yaitu sebelum revisi dan setelah revisi. Setelah dianalisis, hasil rata-rata validator tersebut adalah sebagai berikut:
Tabel 11. Hasil Rata-Rata Validasi Ahli Materi

\begin{tabular}{ccc}
\hline & $\begin{array}{c}\text { Skor } \\
\text { Rata-Rata }\end{array}$ & Keterangan \\
\hline $\begin{array}{c}\text { Validasi ahli materi } \\
\text { sebelum revisi } \\
\begin{array}{c}\text { Validasi ahli materi } \\
\text { setelah revisi }\end{array}\end{array}$ & 3,9 & Valid \\
\hline
\end{tabular}

Pada Tabel 11 dapat dilihat hasil rerata validasi Ahli, bahwa pada kriteria ketuntasan terjadi peningkatan yang sebesar 0,8 dengan keterangan yang awalnya Valid menjadi Sangat Valid. Hal ini membuktikan bahwa media pembelajaran sangat baik digunakan untuk anak Tunagrahita dan sesuai dengan materi Bilangan. Saran dan kritik dari ahli materi adalah pada soal tes siswa lebih disederhanakan lagi karena anak Tunagrahita kurang memahami soal tes nomor 10 dan kalimat yang digunakan saat menerangkan materi lebih disederhanakan lagi.

Setelah divalidasi oleh ahli media dan ahli materi, media pembelajaran PANCORAN juga dinilai oleh satu praktisi/guru, yakni Guru Matematika SDLB Tunas Bangsa Balikpapan. Validator menilai media pembelajaran yang dikembangkan dengan melihat aspek keterlaksanaan pembelajaran dalam kelas. Setelah dianalisis, hasil kriteria ketuntasan validator sebagai berikut:

Tabel 12. Hasil Rata-Rata Validasi Praktisi/Guru

\begin{tabular}{ccc}
\hline & $\begin{array}{c}\text { Skor } \\
\text { Rata-Rata }\end{array}$ & Keterangan \\
\hline $\begin{array}{c}\text { Validasi praktisi/guru } \\
\text { sebelum revisi }\end{array}$ & 3,8 & Praktis \\
$\begin{array}{c}\text { Validasi praktisi/guru } \\
\text { setelah revisi }\end{array}$ & 4,7 & $\begin{array}{c}\text { Sangat } \\
\text { Praktis }\end{array}$ \\
\hline
\end{tabular}

Pada hasil tabel dapat dilihat, bahwa pada kriteria ketuntasan media pembelajaran terjadi peningkatan sebesar 0,9 dengan keterangan yang awalnya Praktis kini menjadi Sangat Praktis. Hal ini membuktikan bahwa media pembelajaran sangat baik digunakan untuk anak Tunagrahita. Saran dan kritik dari praktisi/guru adalah pada media corong angka harus dibuat lebih menarik lagi, seperti mengganti bulatan yang ada di media dengan gambar-gambar yang menarik. 

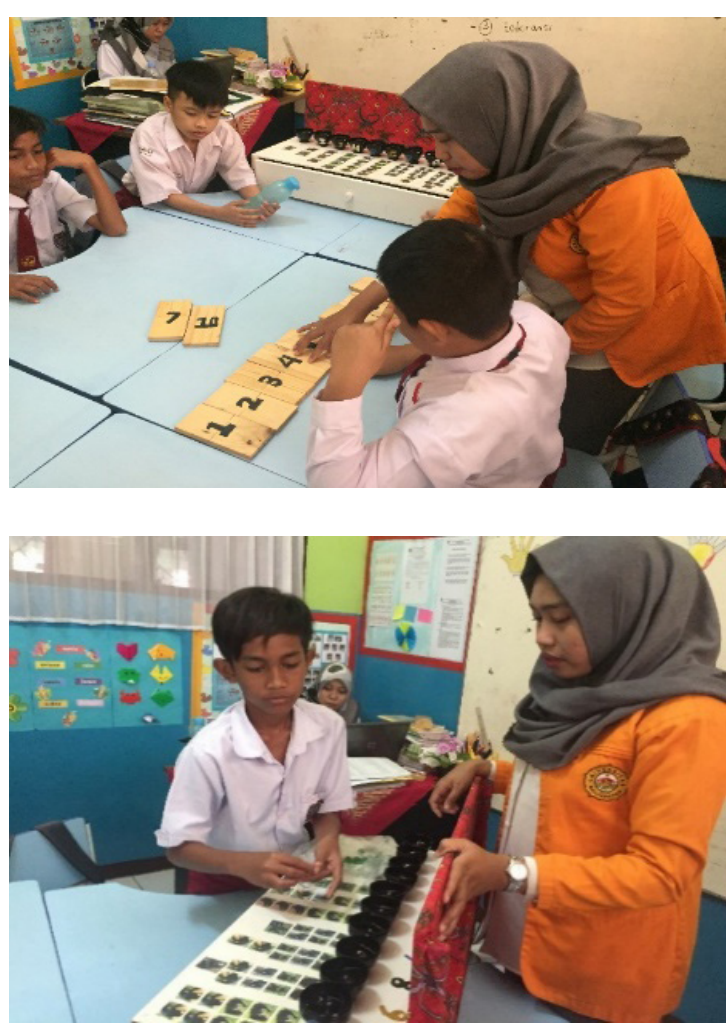

Gambar 6. Pembelajaran menggunakan Puzzle Angka dan Corong Angka (PANCORAN)

Secara keseluruhan, hasil pengembangan media pembelajaran Puzzle Angka dan Corong Angka (PANCORAN) dapat dikatakan layak, yakni memenuhi kriteria kevalidan, kepraktisan, serta keefektifan. Secara detail, berdasarkan Tabel 6 dan Tabel 7, jumlah skor yang diperoleh dari dua ahli media dan dua ahli materi adalah 19 atau dengan kata lain rata-rata skor validasi yang diperoleh adalah sebesar 4,75 (Sangat Valid). Selanjutnya, berdasarkan Tabel 8, skor kepraktisan yang diperoleh adalah sebesar 4,7 (Sangat Praktis), serta berdasarkan Tabel 9, persentase ketuntasan belajar siswa sebesar 80\% (Efektif).

Sebagaimana dibahas sebelumnya, penyampaian materi pelajaran matematika kepada anak berkebutuhan khusus hendaknya memilih dan menggunakan strategi, metode, dan media yang sesuai agar tujuan pembelajaran tercapai dengan baik. Media pembelajaran adalah segala bentuk sesuatu yang dapat menyampaikan dan menyalurkan pesan dari berbagai sumber secara terencana sehingga tercipta lingkungan belajar yang kondusif dimana penerimanya dapat melakukan proses belajar secara efisien dan efektif (Munadi, 2013). Beberapa kajian penelitian juga menunjukkan dampak positif dari pemanfaatan media dalam pembelajaran maatematika, khususnya pada anak tunagrahita. Temuan penelitian ini juga mendukung temuan sebelumnya, diantaranya penelitian yang dilakukan oleh Putri (2014) yang menunjukkan bahwa media Kartu yang Bergambar Domino dapat meningkatkan kemampuan penjumlahan yang hasilnya kurang dari 20 bagi anak tunagrahita ringan, penelitian dari Fauzy (2015) yang menunjukkan bahwa dengan menggunakan media Manik-Manik dapat meningkatkan hasil belajar siswa tunagrahita ringan, penelitian dari Rahmanita \& Samawi (2014) yang menunjukkan bahwa media Kartu Bilangan dapat meningkatkan hasil belajar siswa tunagrahita, penelitian dari Astuti \& Indianto (2014) yang menunjukkan bahwa adanya peningkatan prestasi belajar siswa pada mata pelajaran Matematika dibantu dengan adanya Media Benda Konkret, yaitu dengan menggunakan Batu, Lidi, Sedotan, Permen, Gelas, dan Mangkuk; serta penelitian dari Utami (2017) yang menunjukkan bahwa adanya peningkatan yang signifikan terhadap konsentrasi dan pemahaman konsep angka dan penjumlahan sederhana siswa tunagrahita melalui modifikasi Media Game Adobe Flash.

Media pembelajaran juga memberikan manfaat bagi guru maupun siswa, dalam hal ini bukan hanya anak normal saja yang butuh atau memerlukan media pembelajaran akan tetapi, anak-anak berkebutuhan khusus terutama Tunagrahita juga sangat memerlukan media pembelajaran tentunya media pembelajaran harus disesuaikan dengan keterbatasan anak dan kesulitan yang dialami. Berdasarkan temuan, media pembelajaran PANCORAN membuat siswa yang awalnya kesulitan belajar Materi Bilangan menjadi paham berkat bantuan media pembelajaran.

\section{SIMPULAN}

Berdasarkan hasil penelitian dan pengembangan yang telah dilakukan, dapat disimpulkan bahwa: (1) Media pembelajaran Puzzle Angka dan Corong Angka (PANCORAN) berbasis kearifan lokal Kota Balikpapan yang dikembangkan termasuk dalam kate- 
gori Sangat Valid dengan skor 4,75; (2) Media pembelajaran Puzzle Angka dan Corong Angka (PANCORAN) berbasis kearifan lokal Kota Balikpapan yang telah dikembangkan berdasarkan penilain praktisi termasuk dalam kategori Sangat Praktis dengan skor sebesar 4,$7 ;$ dan (3) Media pembelajaran Puzzle Angka dan Corong Angka (PANCORAN) berbasis kearifan lokal Kota Balikpapan yang telah dikembangkan berdasarkan hasil tes siswa termasuk dalam kategori Sangat Efektif dengan nilai ratarata 81,4 serta presentase ketuntasan belajar siswa sebesar $80 \%$.

\section{DAFTAR PUSTAKA}

Ahmadi, R. (2016). Pengantar Pendidikan: Asas \& Filsafat Pendidikan. Yogyakarta: Ar-Ruzz Media.

Arsyad, A. (2015). Media Pembelajaran. Jakarta: PT. Raja Grafindo Persada.

Astuti, W., \& Indianto, R. (2014, Juni). Penggunaan Media Benda Konkret Untuk Meningkatkan Prestasi Belajar Matematika Anak Tunagrahita Pada Pokok Bahasan Perkalian. Jurnal Rehabilitasi dan Remediasi, I(1), 22-28.

Daryanto. (2013). Media Pembelajaran: Peranannya Sangat Penting Dalam Mencapai Tujuan Pembelajaran. Yogyakarta: Gava Media.

Fauzy, C. (2015, Juli). Peningkatan Hasil Belajar Matematika (Penjumlahan) Melalui Penggunaan Media Manik-Manik Pada Siswa Tunagrahita Ringan Kelas II SLB PGRI Badas Kabupaten Kediri. Jurnal Ortopedagogia, I(4), 336-342.

Gosal, P. H. (2012, November). Kearifan Lokal Masyarakat Minahasa Membangun Rumah Tinggal yang Hijau dan Nyaman. Media Matrasain, VIIII(3), 6781.

Maulida, A., \& Zulfitria. (2017). Pengembangan Kecerdasan Interpersonal Anak Autis Melalui Pemanfaatan Media Puzzle pada Siswa Kelas 2 Sekolah Dasar. Ilmiah PGSD Holistika, 1(2), 121-130.

Munadi, Y. (2013). Media Pembelajaran: Sebuah Pendekatan Baru. Jakarta: Referensi.

Murtie, A. (2016). Ensikopledia Anak Berkebutuhan Khusus. Jogjakarta: Maxima.

Peraturan Pemerintah Republik Indonesia Nomor 72 Tahun 1991

Pratama, R. A. (2018, Maret). Media Pembelajaran Berbasis Articulate Storyline 2 Pada Materi Menggambar Grafik Fungsi di SMP Patra Darma 2 Balikpapan. Dimensi, VII(1), 19-35.

Putri, F. A. (2014, September). Meningkatkan Kemam- puan Penjumlahan Melalui Media Kartu yang Bergambar Domino Pada Anak Tunagrahita Ringan Kelas DIII/C di SLB Limas Padang. E-Jupekhu, III(3), 251-260.

Rahayu, S. M. (2013, Desember). Memenuhi Hak Anak Berkebutuhan Khusus Anak Usia Dini Melalui Pendidikan Inklusif. Jurnal Pendidikan Anak, II(2), 355-363.

Rahmanita, F., \& Samawi, A. (2014, Juli). Penggunaan Media Kartu Bilangan Untuk Meningkatkan Pembelajaran Matematika Anak Tunagrahita di SDLB. Jurnal Ortopedagogia, I(2), 106-111.

Setyosari, P. (2013). Metode Penelitian \& Pengembangan. Jakarta: Kencana.

Shanty, M. (2012). Strategi Belajar Untuk Anak Berkebutuhan Khusus. Yogyakarta: Familia.

Sudana, A. A. (2015). Konsep Dasar Pendidikan Anak Berkebutuhan Khusus. Yogyakarta: Familia.

Sudijono, A. (2010). Pengantar Statistik Pendidikan. Jakarta: PT. Raja Grafindo Persada.

Suparti. (2010, Mei). Penggunaan Media Benda Asli Untuk Meningkatkan Kemampuan Berhitung Anak Tunagrahita Kategori Sedang Kelas Dasar 3 di SLB Bhakti Kencana Berbah. Jurnal Pendidikan Khusus, VI(1), 95-113.

Susanti, Yunus, M., \& Iswari, M. (2013, September). Efektifitas Media Pita Garis Bilangan Dalam Meningkatkan Kemampuan Penjumlahan Bagi Anak Tunagrahita Ringan Kelas DIV/C di SLB Limas Padang. E-JUPEKHU (Jurnal Ilmiah Pendidikan Khusus), II(3), 527-536.

Suwastarini, N. N., Dantes, N., \& Candiasa, I. M. (2015). Pengaruh Implementasi Pembelajaran Berbasis Media Teknologi Informasi dan Komunikasi Terhadap Motivasi dan Hasil Belajar Matematika Siswa SDLB B (Tunarungu) Pada SLB B Negeri PTN Jimbaran. E-Journal, V(1), 1-10.

Undang-Undang Dasar 1945 Pasal 31 Ayat 1

Undang-Undang Nomor 20 Tahun 2003 tentang Sistem Pendidikan Nasional Pasal 32 Ayat 1

Utami, W. Z. (2017, April). Pengembangan Media Pembelajaran Matematika Untuk Meningkatkan Konsentrasi dan Minat Belajar Siswa Tuna Grahita. Jurnal Teknologi Pendidikan, I/(1), 76-87.

Wagiran. (2012, Oktober). Pengembangan Karakter Berbasis Kearifan Lokal Hamemayu Hayuning Bawana (Identifikasi Nilai-Nilai Karakter Berbasis Budaya). Jurnal Pendidikan Karakter, I/(3), 329-339.

Yuliana, R. (2017). Pengembangan Perangkat Pembelajaran dengan Pendekatan PMRI Pada Materi Bangun Ruang Sisi Lengkung Untuk SMP Kelas IX. Jurnal Pendidikan Matematika, VI(1), 60-67. 